\title{
Local reduction of decadal glacier thickness loss through mass balance management in ski resorts
}

\author{
Andrea Fischer ${ }^{1}$, Kay Helfricht ${ }^{1}$, and Martin Stocker-Waldhuber ${ }^{1,2}$ \\ ${ }^{1}$ Institute for Interdisciplinary Mountain Research, Austrian Academy of Sciences, Innsbruck, 6020, Austria \\ ${ }^{2}$ Department of Geography, Physical Geography, Catholic University of Eichstätt-Ingolstadt, Eichstätt, 85072, Germany \\ Correspondence to: Andrea Fischer (andrea.fischer@oeaw.ac.at)
}

Received: 8 March 2016 - Published in The Cryosphere Discuss.: 21 April 2016

Revised: 5 October 2016 - Accepted: 17 October 2016 - Published: 30 November 2016

\begin{abstract}
For Austrian glacier ski resorts, established in the 1970s and 1980s during a period of glacier advance, negative mass balances with resulting glacier area loss and decrease in surface elevation present an operational challenge. Glacier cover, snow farming, and technical snow production were introduced as adaptation measures based on studies on the effect of these measures on energy and mass balance. After a decade of the application of the various measures, we studied the transition from the proven short-term effects of the measures on mass balance to long-term effects on elevation changes. Based on lidar digital elevation models and differential GPS measurements, decadal surface elevation changes in 15 locations with mass balance management were compared to those without measures (apart from piste grooming) in five Tyrolean ski resorts on seven glaciers. The comparison of surface elevation changes presents clear local differences in mass change, and it shows the potential to retain local ice thickness over 1 decade. Locally up to $21.1 \mathrm{~m} \pm 0.4 \mathrm{~m}$ of ice thickness was preserved on mass balance managed areas compared to non-maintained areas over a period of 9 years. In this period, mean annual thickness loss in 15 of the mass balance managed profiles is $0.54 \pm 0.04 \mathrm{~m} \mathrm{yr}^{-1}$ lower $\left(-0.23 \pm 0.04 \mathrm{~m} \mathrm{yr}^{-1}\right.$ on average) than in the respective reference areas $\left(-0.78 \pm 0.04 \mathrm{~m} \mathrm{yr}^{-1}\right)$.

At two of these profiles the surface elevation was preserved altogether, which is promising for a sustainable maintenance of the infrastructure at glacier ski resorts. In general the results demonstrate the high potential of the combination of mass balance management by snow production and glacier cover, not only in the short term but also for multi-year application to maintain the skiing infrastructure.
\end{abstract}

\section{Introduction}

During the last 3 decades, Alpine glaciers have retreated drastically and increasingly, with current annual rates at historically unprecedented levels (Zemp et al., 2015). Globally, glacier mass balances have been increasingly negative (Vaughan et al., 2014), leading to additional river runoff in glacier-covered basins (Kovats et al., 2014). In Asia, glacier retreat is likely to affect water scarcity (Hijioka et al., 2014). In the European Alps, glaciers are part of the national economy, contributing to hydropower production and as part of ski resorts. Glacier ski resorts are located at high elevations and thus are less affected by a decrease in depth and43). Recently, mass balance management methods have been developed to store and maintain snow in ski resorts (Skogsberg and Lundberg, 2005; Spandre et al., 2016; Grünewald and Wolfsperger, 2016) and manage meltwater production (Nestler et al., 2014; Norphel and Padma, 2015). In the Austrian Alps, mass balance management in glacier ski resorts started after the extreme melt in the summer of 2003 (Fischer et al., 2011a) to compensate for the negative effects of glacier retreat on ski resort infrastructure. This paper presents the long-term effects of the measures on local glacier elevation change.

Austria's glaciers experienced a reduction by $26 \%$ in area in recent decades (first glacier inventory GI1 1969third glacier inventory GI3 2006/2012; Fischer et al., 2015). Abermann et al. (2009) found mean thickness changes of $0.95 \mathrm{~m} \mathrm{yr}^{-1}$ between 1969 and 1997 and $-0.91 \mathrm{~m} \mathrm{yr}^{-1}$ between 1997 and 2006 for the glaciers in Ötztal. Since the extreme summer of 2003, we have seen several years with negative mass balances in all elevation zones. The glacier changes 

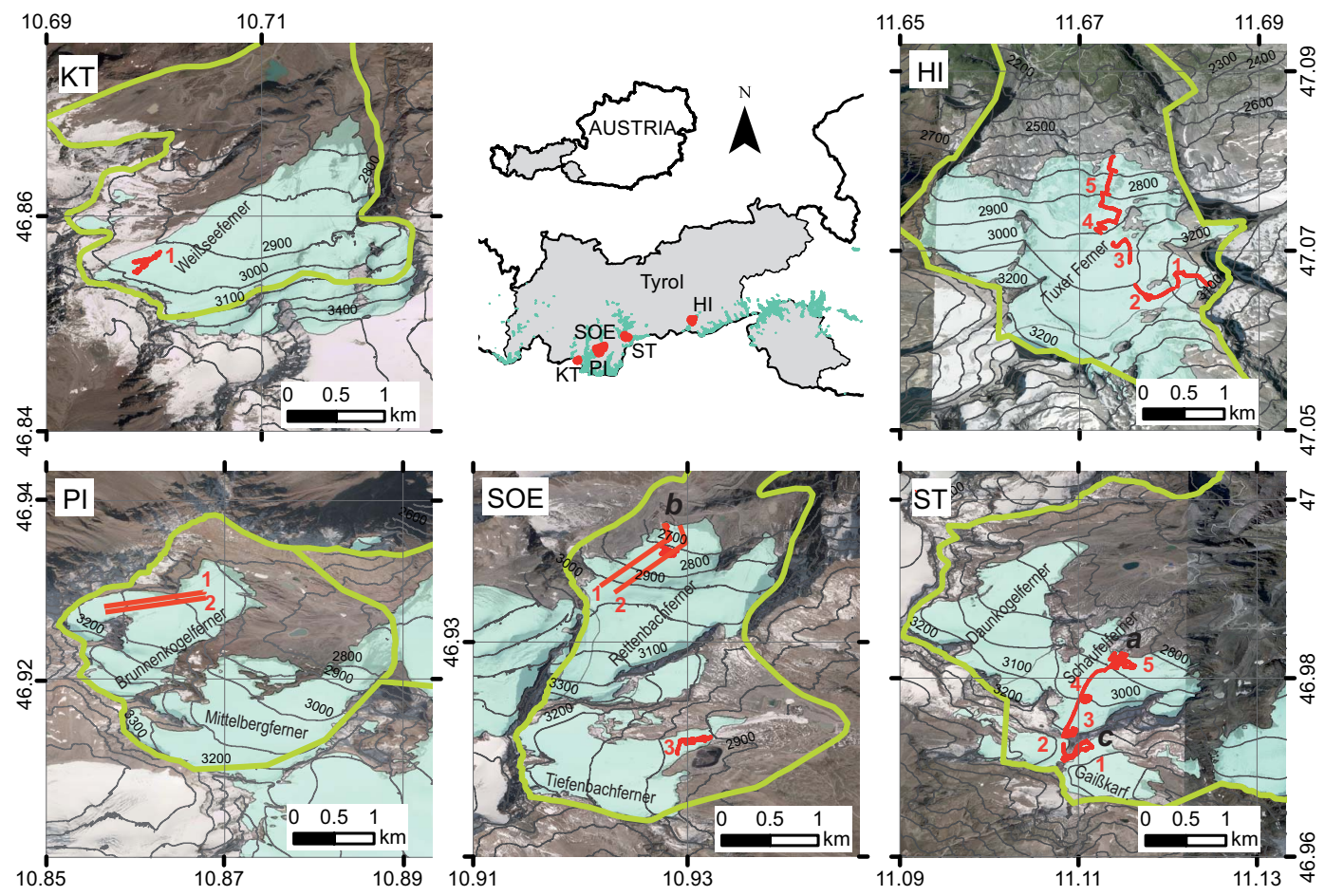

Figure 1. Overview of the Tyrolean glacier ski resorts of Kaunertal (KT), Pitztal (PI), Sölden (SOE), Stubai (ST), and Hintertux (HI). Measurement locations (red lines) with profile numbers (red), ski resort outlines (green lines), glaciers assigned to the resort (light green), and contour lines of the GI3 DEMs superimposed on orthophotos (http://tirol.gv.at). Areas a-c are shown in Fig. 2.

Table 1. Glacier ski resorts in Austria with opening year, federal state, glacier names, the total glacier area, the glacier area assigned to the ski resort, and the relative area of the ski resort on glacier with mass balance management (mbm).

\begin{tabular}{|c|c|c|c|c|c|c|}
\hline Ski resort & $\begin{array}{l}\text { Opening } \\
\text { year }\end{array}$ & State & Glaciers & $\begin{array}{l}\text { Total glacier } \\
\text { area }\left(\mathrm{km}^{2}\right)\end{array}$ & $\begin{array}{l}\text { Ski resort area on } \\
\text { glacier }\left(\mathrm{km}^{2}\right)\end{array}$ & $\begin{array}{r}\text { Area of } \\
\text { mbm }(\%)\end{array}$ \\
\hline Kitzsteinhorn & 1965 & Salzburg & Schmiedinger Kees & 1.16 & 1.16 & - \\
\hline Dachstein Glacier ${ }^{a}$ & 1969 & Upper Austria & Schladminger Glacier & 0.71 & 0.71 & - \\
\hline Hintertux Glacier ${ }^{b}$ & 1969 & Tyrol & Gefrorene-Wand-Kees, Riepenkees & 4.56 & 4.56 & 2.9 \\
\hline Stubai Glacier a,b & 1972 & Tyrol & $\begin{array}{l}\text { Schaufelferner, Daunkogelferner, } \\
\text { Fernauferner, Windacher Ferner, } \\
\text { Gaißkarferner }\end{array}$ & 4.48 & 4.10 & 2.4 \\
\hline Sölden a,b & 1975 & Tyrol & Rettenbachferner, Tiefenbachferner & 2.76 & 2.76 & 2.2 \\
\hline Pitztal Glacier ${ }^{\text {a,b }}$ & 1983 & Tyrol & Mittelbergferner, Brunnenkogelferner & 10.94 & 3.39 & 2.1 \\
\hline Kaunertal Glacier ${ }^{\mathrm{a}, \mathrm{b}}$ & 1980 & Tyrol & Weißseeferner & 2.64 & 2.13 & 6.6 \\
\hline \multirow[t]{2}{*}{ Mölltal Glacier } & 1986 & Carinthia & Wurten Kees & 0.05 & 0.05 & - \\
\hline & & & Total & 25.43 & 16.94 & 3.0 \\
\hline
\end{tabular}

${ }^{\text {a }}$ Ski resorts with preparatory studies to mass balance management measures.

b Ski resorts with data analysed in this study.

- not measured.

of the last 3 decades were challenging for the eight Austrian glacier ski resorts (Table 1, Fig. 1), which are located on 15 glaciers. They started operation between 1969 and 1986, when up to $72 \%$ of the Austrian glaciers were advancing (Fischer et al., 2013b). During the early years of the glacier ski resorts, the main skiing season was during summer, with some of the resorts even being closed during winter. In recent decades there has been less demand for summer skiing and the main season has shifted to autumn and spring. Most resorts open during summer for hikers and mountaineers only. Diolaiuti et al. (2006) investigated glacier evolution and summer skiing at Vadretta Piana (Stelvio Pass, Italy). They noticed that, although the glacier has receded, single years of exceptional good conditions for glacier summer skiing can 
still result in a high number of skiers. A comparative study on the impact of glacier changes on mountain tourism was presented by Smiraglia et al. (2008).

Not only visitor demand but also cable car technology has become more sophisticated over time, and with it demands on glacier conditions have risen. Initially it was mainly towlifts operating on the glacier, low installations with adjustable pylons to compensate for glacier flow and mass balance. As these lifts transport the skiers along the ground, they are technically easier to maintain and have less strict corridors for compensating glacier motion and mass balance. However, tow-lifts need a route with a gentle slope. Nowadays, chair lifts and circulating ropeways are built with much higher pylons and bearing loads. While these lift types can also be built in complex terrain of steep slopes or rock cliffs, there are strict limits on the acceptable inclination of the pylons. Apart from lift infrastructure, pistes on the glacier surface have to fulfil specific requirements regarding width and steepness. The transition of the ski tracks from glacier to the bare ground changes constantly, as the glacier area and elevation changes.

The loss of firn reservoirs, increase of debris on the glacier surface by melt and rock falls (Fischer, 2010), as well as more and deeper supraglacial channels increase surface roughness on glaciers, so that more snow is needed in grooming to smooth pistes (Fischer et al., 2011a). Where glacier ice has disappeared, bare ground is often steeper than and not as smooth as the former glacier surface. Pistes which became ice free have had to be rerouted to meet the requirements on width and difficulty. Sinking glacier surfaces often make exit and entrance to summit or valley lift stations difficult. Steeper glacier surfaces complicate the maintenance of traverse pistes and increase the danger of avalanches. As the ropeway pylons are mounted on sledges designed for specific pylon shifts, changes in the flow regime, i.e. velocity and/or direction, shorten maintenance windows. In the worst case, sinking surfaces lead to angles and bearing loads which are out of the approved range for that installation, so that the ropeway has to be replaced or adapted. One positive effect of the years with negative mass balances was the decrease of ice flow velocities, which led to a reduction of the number and size of crevasses (Colgan et al., 2016; Fischer, 2010; Pelto and Hedlund, 2001) in glacier ski resorts (e.g. Fischer et al., 2011a; Diolaiuti et al., 2006).

Therefore, mass balance management in glacier ski resorts has three aims:

i. decreasing the surface roughness by retaining snow over the summer (including keeping smooth firn or snow cover on bare and rough glacier ice, crevasses and supraglacial rivers, rock, and debris);

ii. retaining surface elevation around infrastructure;

iii. preventing or reducing ice melt to keep bedrock icecovered.
In previous studies at the glacier ski resorts in Tyrol (Austria), and later also at Dachstein Glacier ski resort, several methods for mass balance management in glacier ski resorts were investigated by extensive field work and modelling (Olefs and Fischer, 2008; Olefs and Obleitner, 2007; Olefs and Lehning, 2010):

$$
\begin{aligned}
& \text { - glacier covers } \\
& \text { - grooming } \\
& \text { - water injection } \\
& \text { - snow-farming. }
\end{aligned}
$$

Glacier covering means insulating the glacier surface with an approx. $0.002 \mathrm{~m}$ thick white polypropylene fabric in the period between peak accumulation (mid-May) and the start of the accumulation season (early September). Piste grooming is regular mechanical preparation of the ski piste by snowcat during operation (i.e. between September and May). Water injection aims at the infiltration and refreezing of liquid water in the snow layer to increase density and is used more to prepare pistes for ski races than for mass balance management. Snow-farming summarizes efforts to amass snow accumulated from wind drift, technically produced snow and snow from avalanche deposits, which is relocated by snowcats to create snow depots or increase accumulation on the piste.

In the study of Olefs and Fischer (2008), glacier cover was by far the most effective method and reduced ablation by $60 \%$. In case enough snow was accumulated during the winter or brought in with snowcats or wind drift, local annual mass balance even went positive during the experiments. Grooming without other measures reduced ice ablation by $6 \%$, which is close to measurement uncertainty. The exact physical mechanism is unclear. We measured a higher accumulation in the groomed areas at the end of the winter, potentially caused by limited wind erosion of snow (Fischer et al., 2011a). We cannot exclude other reasons for increased accumulations, such as modification of surface albedo or modifications of thermal conductivity. Fahey et al. (1999) observed up to $45 \%$ more water available on groomed pistes compared to non-groomed slopes. The application of water injection into the snowpack was not developed further. It increases the mechanical resistance of the piste but has little effect on local glacier mass balance (Olefs and Fischer, 2008). As all measures are costly and need much manpower, application is limited to small areas, which have been identified as areas where sinking surface elevation, bare ground, or steep slopes would do the most harm to the infrastructure. Thus mass balance management is applied only on less than $10 \%$ of the ski resorts glacier area, with mean values of about $3 \%$, limiting the impact of the measures to hydrology and total glacier mass balance. As an additional method, snow production facilities have by now been installed at a number of ski resorts, providing snow on pistes for an early season start even on 
Table 2. Dates of the surface elevation information in the different glacier ski resorts from digital elevation models (DEM) based on orthophotos (O), airborne laser scanning surveys (ALS), and differential GPS measurements (DGPS).

\begin{tabular}{lllll}
\hline & \multicolumn{3}{c}{ Period 1 } \\
\cline { 3 - 5 } Ski resort & \multicolumn{3}{c}{ Period 2 } \\
\cline { 3 - 5 } & DEM GI2 (O) & DEM GI3 (ALS) & DEM (ALS) & DGPS \\
\hline Hintertux Glacier & 1999 & 2007 & - & $03 / 08 / 2015$ \\
Stubai Glacier & 1997 & 2006 & - & $06 / 07 / 2015$ \\
Sölden Glacier & 1997 & 2006 & 2014 & $16 / 07 / 2015$ \\
Kaunertal Glacier & 1997 & 2006 & 2012 & $23 / 07 / 2015$ \\
Pitztal Glacier & 1997 & 2006 & 2014 & - \\
\hline
\end{tabular}

bare ice surfaces, when firn cover is missing, and to reduce ice ablation in summer.

After a decade of measuring the glaciers, the question arises of the long-term outcome of these measures: Although the short-term effect has been proven, it could be that measures have not been applied frequently enough to return a sustainable result. Moreover, ice dynamics might lead to a redistribution of masses so that, for example, no effect on surface elevations would be measurable. From this basic research question, this study aimed at assessing long-term net effects of mass balance measures on volume changes by comparing surface elevation changes in areas which have been subject to different types of mass balance management and neighbouring areas without such management. This study aims at comparing elevation changes on experimental and reference areas rather than at inferring mass balance from elevation changes. Surface elevation changes in mass balance managed (i.e. experimental) areas were compared to neighbouring (i.e. reference) areas of the same elevation and exposure without such measures (apart from some grooming of pistes). The comparison was done for two time periods. The first is given by the date of the glacier inventory digital elevation models (DEMs). Mass balance management measures started at the end of the first period. The effect of the mass balance management is investigated by (i) comparing the first period (with mass balance management only applied in the last years) to the second period (mass balance management in the full period) and (ii) comparing managed and unmanaged areas in period 2. The investigated measures were accumulation by snow production and movement of snow with snowcats in combination with glacier covers.

\section{Data and methods}

\subsection{Elevation data}

For the calculation of thickness changes, three different sources of elevation information have been used in this study (Table 2). For all test sites, DEMs from the second (GI2, 1997 and 1999) and third (GI3, 2006/2007) glacier inven- tories were used. The DEMs of GI2 are based on photogrammetry and the DEMs of GI 3 on lidar imagery. All DEMs are referenced to the official Austrian geodata. Three test sites have been covered by recent high precision lidar DEMs. To capture the thickness changes at all sites up to 2015, surface elevation was recorded with differential GPS (DGPS) along profiles.

\subsubsection{Photogrammetric DEMs}

The DEMs of the second (GI2) Austrian glacier inventory (Lambrecht and Kuhn, 2007) are based on orthophotos with $5 \mathrm{~m}$ grid size. The DEMs have been calculated with a semiautomatic method in a $20 \mathrm{~m}$ grid (Würländer and Eder, 1998). The minimum vertical accuracy had been defined as $\pm 1.9 \mathrm{~m}$ (Lambrecht and Kuhn, 2007) but turned out to be better than $\pm 0.71 \mathrm{~m}$ by Würländer and Eder (1998). In shadowed or oversaturated parts of the orthophotos, local errors can be larger, as shown by Abermann et al. (2007) who compared in situ measurements on Kesselwandferner in the Ötztal Alps with DEM data. There is no indication that any of the DEMs of the test sites in this study are outside the error margin of $\pm 0.71 \mathrm{~m}$ found by Würländer and Eder (1998), as the respective orthophotos did not present oversaturation or shadows. The orthophotos were taken in August and September, close to the seasonal minimum snow cover.

\subsubsection{Lidar DEMs}

The airborne lidar DEMs of the third glacier inventory were recorded by the Federal Government of Tyrol with ALTM 3100 and Gemini sensors at a density of four points per square metre. The vertical accuracy is $\pm 0.1 \mathrm{~m}$ (Abermann et al., 2010). Studies on the accuracy of lidar DEMs by Bollmann et al. (2011), Joerg et al. (2012), Deems et al. (2013), and Sailer et al. (2014) confirm measurement accuracies better than $\pm 0.2 \mathrm{~m}$ for flat areas. Fischer et al. (2011b) compared in situ measurements and lidar altitudes of 51 periglacial ground control points, suggesting an accuracy of the lidar DEM better than $\pm 0.3 \mathrm{~m}$. The lidar DEMs were recorded in late August and September, close to the seasonal minimum 
snow cover. Lidar DEMs of the years 2012 and 2014 have been produced on the basis of airborne laser scanning surveys (ALS) surveys in close cooperation with the glacier ski resorts.

\subsubsection{GPS measurements}

We recorded the surface elevation along profiles using a TOPCON HiPer V Dual-Frequency GNSS Receiver. Raw DGPS data were corrected in post-processing (software: Topcon Magnet Tools) with data of the reference stations Merano, Bolzano, Vipiteno, and Malles Venosta provided by the Autonomous Province of South Tyrol/Alto Adige (http: //www.stpos.it/SpiderWeb/frmIndex.aspx). The standard deviations (as calculated by Magnet Tools) of the corrected data are $0.07 \mathrm{~m}$ (vertical) and $0.15 \mathrm{~m}$ (horizontal). The uncertainty of the vertical component of the DGPS location is assumed to be $1 \mathrm{~m}$ (e.g. Monteiro et al., 2005). The DGPS surveys took place in July and August, with a snow-covered area similar to the DEM data. In rather steep terrain, horizontal dislocation increases the vertical error.

\subsection{Calculation of thickness changes}

The thickness change at a single location $\Delta z$ results from subtracting the altitude at the dates of the second survey from those of a first survey. The mean thickness change of a profile is the average of the thickness changes of every point within the profile. Elevation changes between DEM and DGPS data were calculated at every point recorded by DGPS using ArcGIS (version 10.2.2) and MATLAB R2014b. Elevation values were extracted from the DEM rasters of the different dates using "extract values to points" and surface elevation changes were obtained from these values at every point in the attribute table. Thickness changes between two DEMs were calculated along a profile line at equidistant nodes $1 \mathrm{~m}$ apart, which show similar point densities to the DGPS measurements.

The measurement errors of the thickness changes at one location are the sum of the measurements errors of each surface elevation data set (to find a maximum error). This results in $0.7 \mathrm{~m}$ for the thickness change between the second and the third glacier inventory DEMs, $0.27 \mathrm{~m}$ for the thickness change calculated from the third glacier inventory DEMs, and DGPS data and $0.4 \mathrm{~m}$ for lidar DEM differences.

Systematic errors of the thickness change result from positioning of the DGPS antenna above ground, different information content in raster and point data of elevation, as well as seasonal snow cover. To prevent shading of the signal, the DGPS antenna was mounted on a stake or a backpack during the measurements. Penetration of the stake in the snow, deviations from the perpendicular or other deviations from the recorded mounting positions can affect individual measurements within a range of centimetres. The DEM altitude is the mean altitude within the pixel located at the DGPS measure-
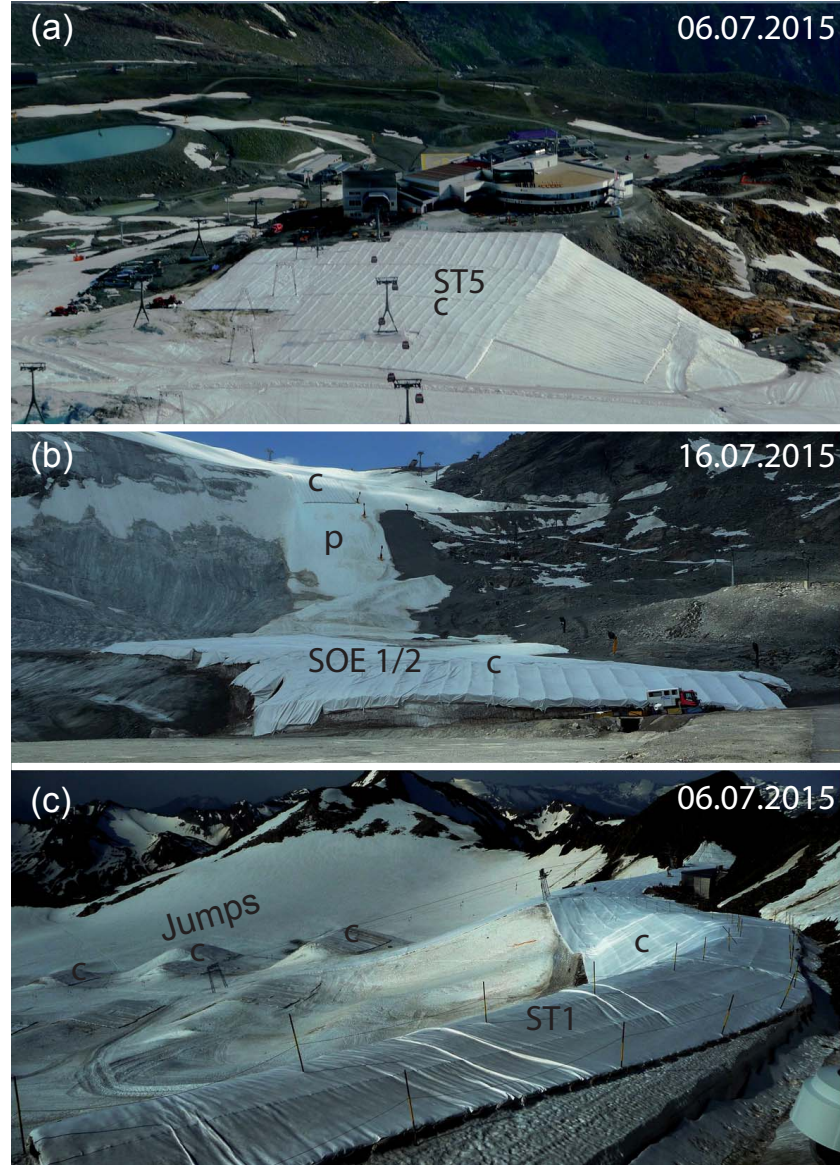

Figure 2. Mass balance management at profiles ST5 (a, Stubai glacier ski resort; for hillshade and thickness change see Fig. 3), SOE1/2 (b, Sölden ski resort), and ST1 (c, Stubai Glacier ski resort) with applied measures: "c" indicates covers; "p" indicates snow production.

ment point. As the lidar data are based on four pixels $\mathrm{m}^{2}$ and have a spatial resolution of $1 \times 1 \mathrm{~m}$, the spatial resolution can be considered similar to the DGPS measurements (acquired every second at walking speed, resulting in a point density of 1-2 points per metre. The DEMs of the second glacier inventory were processed in a $20 \times 20 \mathrm{~m}$ grid and resampled to a $5 \times 5 \mathrm{~m}$ grid. As these were recorded before mass balance management started, the glacier surface was smooth, so that the deviations within one pixel from the pixel mean result from the surface slope, which is lower than $20^{\circ}$ in the test sites. Therefore the difference of point altitudes from the mean within the grid cells is less than $1.3 \mathrm{~m}$ for slopes with $20^{\circ}$ and less than $0.08 \mathrm{~m}$ for slopes with $5^{\circ}$.

All the elevation data were recorded during ablation season, with major parts of the glacier presenting bare ice. As every year and every region show a different course of accumulation and ablation, it is not possible to survey each site at its individual minimum of mass. Although minor impacts of old snow (from the winter) cannot be excluded, all data 
were recorded in the absence of new snow, thus neglecting the effect of seasonal snow cover. In any case, the time span of 1 decade includes considerable interannual variability in glaciological and meteorological parameters. The effect of old snow, confined to highest elevations at the survey dates, is less than the year-to-year variability, as the early date of the survey in 2015 coincides with extreme melt rates and early recession of snow cover.

\subsection{Study sites}

During 2003-2009, areas with mass balance management on Stubai Glacier, Pitztal Glacier, Kaunertal Glacier, and Sölden Glacier ski resort were monitored extensively, with at least two surveys per annum and a maximum of weekly surveys on Stubai Glacier. After finishing these projects, the sites were still monitored on an annual basis with some ablation stakes and a photographic documentation of the evolution of the glacier surface. Based on this documentation, areas with continuous mass balance measured within these ski resorts were selected for this study. Although not included in the initial research projects 2003-2009, sites in the Hintertux Glacier ski resort were added to this study, as these are the sites with the longest history of mass balance management by on-glacier snow production. Mass balance management takes place in areas where technical infrastructure located on solid ground is adjacent to ski pistes on glacier parts with high subsidence rates and at pylons on glacier or boarder parks with jumps and pipes. Three representative locations with mass balance management are shown in Fig. 2. The middle station at Schaufelferner (Fig. 2a) is located on a rock, with the surrounding glacier showing high subsidence rates. Glacier covers have been applied since 2004 to allow access to and exit from the station. The steepening tongue of Rettenbachferner is kept in shape with a combination of snow production and covers to provide easy access to the valley station, where the photograph in Fig. $2 b$ was taken. The subsidence of glacier surface is most extreme at the tongues but also takes place at highest elevations. The most disturbing effects are observed close to the cols and at the transition to solid ground in highest elevations. The exit from the top station, where the photo in Fig. 2c was taken, crosses a steepening and subsiding slope, which is kept in shape and at the same altitude by covers. The upper left side of the photo shows covered snow/firn hills used as jumps for snow boarders and free skiers. The lidar DEM hillshade of the site ST5 in Fig. 2a shows the location of the prominent glacier covers, with clearly lower thickness losses than the surroundings (Fig. 3).

In the five glacier ski resorts (Table 1), 15 sites with mass balance management were selected for comparing thickness changes in managed and reference areas. The comparison was carried out for two time periods. Reference profiles are located within the pistes close to the mass balance managed profiles in similar settings in terms of slope, aspect, shade, and snow accumulation.

\section{Results}

In general, in the last decade a balance of the surface elevation at the highest investigated elevations could be achieved by snow grooming and by covering the glacier. At profile ST5 (Fig. 4), a nearly constant surface elevation at the glacier terminus during the second period is a consequence of constant piste grooming, relocation of snow, and glacier cover. In the reference area, without application of mass balance management, surface elevation loss of the second period was in the same magnitude as in the first period. Graphs similar to Fig. 4 are shown in the supplementary material for all profiles.

To provide a general overview, the thickness changes at all profiles during the two periods (Table 3 ) are divided into tho categories for further analysis:

- profiles close to the glacier terminus in similar topographic settings, resulting in similar thickness loss at mass balance management profiles and reference profiles during the first period (Fig. 5);

- profiles at higher elevations with differences in thickness loss at mass balance management profiles and reference profiles during the first period (Fig. 6).

For the first category, during the first period reference and mass balance management, thickness changes are quite similar and range between -0.53 and $-2.03 \mathrm{~m} \mathrm{yr}^{-1}$. During the second period, reference area thickness losses increased for SOE $1+2$ and HI 4 and decreased for the other profiles (all values within measurement uncertainties). In all profiles, mass balance management thickness losses decreased between the first and the second period, ranging from 0.01 to $-0.94 \mathrm{~m} \mathrm{yr}^{-1}$. In contrast to the smaller thickness losses in mass balance managed areas, reference areas lost a thickness of -0.55 to $-1.81 \mathrm{~m} \mathrm{yr}^{-1}$. The calculated changes for the second period are larger than the measurement errors. The mean thickness loss in mass balance managed profiles is $-1.12 \mathrm{~m}$ for the first period and $-0.34 \mathrm{~m} \mathrm{yr}^{-1}$ in the second period. The respective losses in reference areas are -1.19 and $-1.12 \mathrm{~m} \mathrm{yr}^{-1}$. Thus the difference in thickness loss between managed and unmanaged areas is $0.77 \mathrm{~m} \mathrm{yr}^{-1}$ on average during the second period.

This study focuses on the analysis of glacier surface elevation changes, as these are a major challenge for the operation of the ski resorts. Although thickness changes for managed and unmanaged areas are compared, it is outside the scope of this study to infer information on (unmeasured) mass balances from (measured) thickness changes. The interpretation of surface elevation changes in terms of mass balance is not possible without additional information. In the ablation area 
Table 3. Mean elevation of the profiles and the applied mass balance management measures (mbm) snow production (p), snow relocation $(\mathrm{r})$, snow covering $(\mathrm{c})$, and piste grooming $(\mathrm{g})$. The mean $(\mu)$ and the standard deviation $(\sigma)$ of surface elevation changes in metres for experimental areas (exp) and reference areas (ref) at the profiles in the periods without (p1) and with (p2) mass balance management are shown. Absolute differences (abs. diff, in metres) of the exp mean values to the ref mean values are given. Note that the arrangement of the profiles corresponds to the segmentation of the profiles in Figs. 5 and 6.

\begin{tabular}{|c|c|c|c|c|c|c|c|c|c|c|c|c|c|c|c|}
\hline \multirow{3}{*}{$\begin{array}{l}\text { Profile } \\
\text { name }\end{array}$} & \multirow{3}{*}{$\begin{array}{l}\text { Mean } \\
\text { elevation } \\
\text { (m a.s.l.) }\end{array}$} & & & & & \multicolumn{5}{|c|}{ Thickness change in period $1(\mathrm{~m})$} & \multicolumn{5}{|c|}{ Thickness change in period $2(\mathrm{~m})$} \\
\hline & & & \multirow{2}{*}{\multicolumn{3}{|c|}{$\mathrm{mbm}$}} & \multicolumn{2}{|c|}{ ref } & \multicolumn{2}{|c|}{$\exp$} & \multirow{2}{*}{$\begin{array}{r}\text { abs. } \\
\text { diff }\end{array}$} & \multicolumn{2}{|c|}{ ref } & \multicolumn{2}{|c|}{$\exp$} & \multirow{2}{*}{$\begin{array}{r}\text { abs. } \\
\text { diff }\end{array}$} \\
\hline & & & & & & $\mu$ & $\sigma$ & $\mu$ & $\sigma$ & & $\mu$ & $\sigma$ & $\mu$ & $\sigma$ & \\
\hline HI3 & 2976 & $\mathrm{p}$ & & $\mathrm{c}$ & $\mathrm{g}$ & -6.0 & 2.1 & -4.2 & 1.3 & 1.7 & -5.8 & 1.1 & -0.9 & 2.5 & 4.9 \\
\hline HI4 & 2870 & $\mathrm{p}$ & & $\mathrm{c}$ & $\mathrm{g}$ & -4.2 & 1.4 & -5.7 & 1.2 & -1.4 & -6.0 & 1.1 & 0.1 & 1.1 & 6.1 \\
\hline HI5 & 2742 & $\mathrm{p}$ & $\mathrm{r}$ & $\mathrm{c}$ & $\mathrm{g}$ & -9.2 & 4.2 & -8.9 & 3.2 & 0.3 & -4.4 & 4.7 & -2.8 & 2.5 & 1.6 \\
\hline SOE $1+2$ & 2769 & $\mathrm{p}$ & $\mathrm{r}$ & $\mathrm{c}$ & $\mathrm{g}$ & -12.7 & 7.3 & -12.8 & 5.0 & -0.1 & -14.5 & 6.5 & -7.5 & 4.0 & 7.0 \\
\hline SOE1a & 2703 & $\mathrm{p}$ & $\mathrm{r}$ & $\mathrm{c}$ & $\mathrm{g}$ & -18.3 & 1.2 & -15.3 & 3.9 & 2.9 & -16.1 & 3.6 & -4.4 & 3.6 & 11.8 \\
\hline SOE3 & 2940 & & $\mathrm{r}$ & $\mathrm{c}$ & $\mathrm{g}$ & -12.2 & 0.7 & -12.6 & 1.9 & -0.3 & -10.1 & 1.1 & -3.5 & 2.5 & 6.6 \\
\hline ST5 & 2884 & & $\mathrm{r}$ & $\mathrm{c}$ & $\mathrm{g}$ & -9.8 & 1.0 & -8.5 & 2.4 & 1.4 & -9.6 & 1.6 & -1.2 & 4.5 & 8.3 \\
\hline HI1 & 3167 & & $\mathrm{r}$ & $\mathrm{c}$ & $\mathrm{g}$ & -1.3 & 2.8 & -2.9 & 3.1 & -1.6 & -2.4 & 2.5 & -0.3 & 1.5 & 2.0 \\
\hline HI2 & 3038 & & $\mathrm{r}$ & $\mathrm{c}$ & g & -4.2 & 0.5 & -3.1 & 0.4 & 1.1 & -5.3 & 1.3 & -4.3 & 0.9 & 1.1 \\
\hline ST1 & 3141 & & $\mathrm{r}$ & $\mathrm{c}$ & $\mathrm{g}$ & -7.4 & 3.8 & -0.7 & 3.1 & 6.7 & -4.7 & 2.4 & 2.2 & 1.9 & 6.9 \\
\hline ST2 & 3135 & & & $\mathrm{c}$ & $\mathrm{g}$ & 0.2 & 2.9 & -0.7 & 2.9 & -0.9 & 1.2 & 0.4 & 1.6 & 0.8 & 0.3 \\
\hline ST3 & 3102 & & & $\mathrm{c}$ & $\mathrm{g}$ & -3.6 & 0.4 & -0.2 & 2.0 & 3.5 & 0.5 & 2.1 & 4.2 & 1.9 & 3.8 \\
\hline ST4 & 3000 & & $\mathrm{r}$ & $\mathrm{c}$ & $\mathrm{g}$ & -5.8 & 0.8 & -4.9 & 0.6 & 0.9 & -6.3 & 1.4 & -3.8 & 1.8 & 2.5 \\
\hline PI1+2 & 3041 & & $\mathrm{r}$ & $\mathrm{c}$ & $\mathrm{g}$ & -10.1 & 1.6 & -10.0 & 2.0 & 0.1 & -9.6 & 1.6 & -7.1 & 2.8 & 2.5 \\
\hline KT1 & 2962 & & $r$ & $\mathrm{c}$ & $\mathrm{g}$ & -4.7 & 1.6 & -4.0 & 2.0 & 0.7 & -12.4 & 1.0 & -3.9 & 3.4 & 8.5 \\
\hline
\end{tabular}
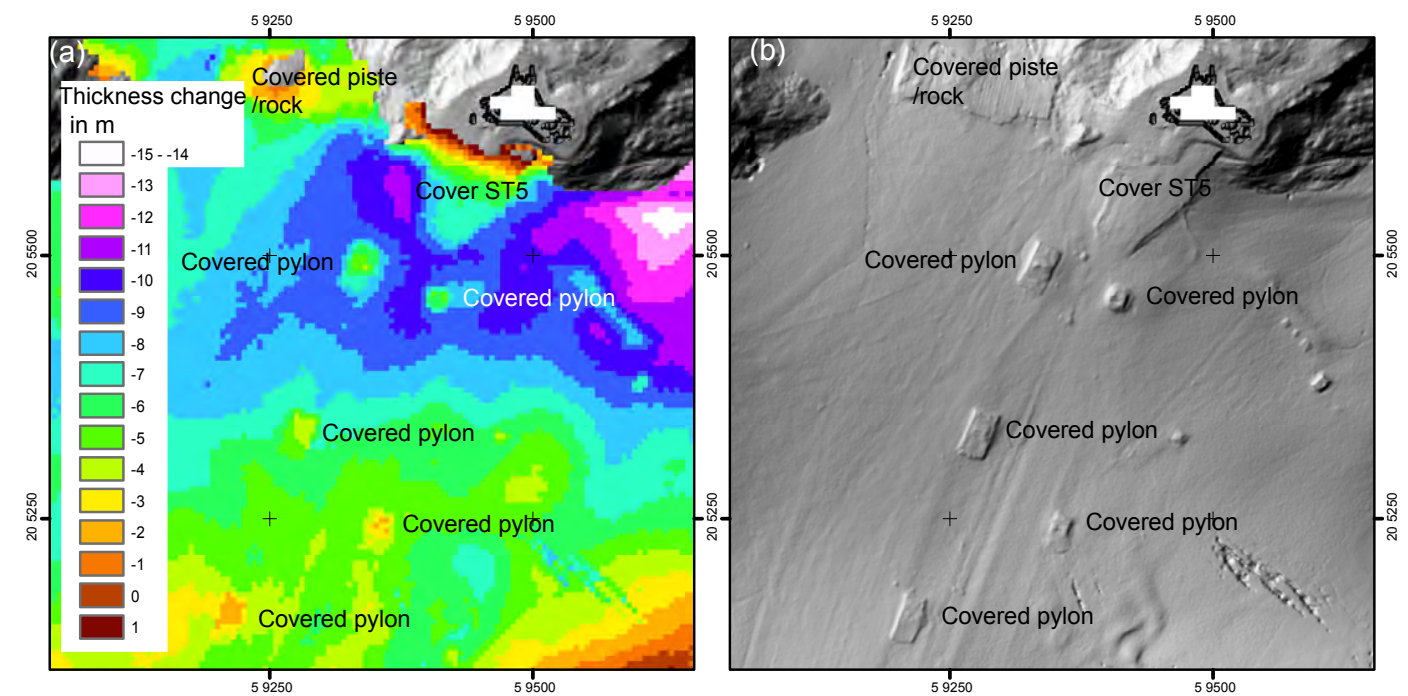

Figure 3. The thickness changes on Schaufelferner (Stubai glacier ski resort) at the location of the mass balances measures (a) on the lidar DEM hillshade of 2006 are lower than in the surroundings (b).

emergence reduces surface elevation loss by ablation, so that ablation generally is higher than surface elevation decrease. In the accumulation area, accumulation is higher than surface elevation change as submergence takes place. Local surface elevation changes can result not only from surface mass balance but also from subglacial erosion, internal, and basal melt and density changes (Cogley et al., 2011). These factors are usually neglected in glacier-wide geodetic mass balance studies, and we have no indication that they would play a major role in our study.

Surface elevation changes $\frac{\partial S}{\partial t}$ result from glacier dynamics, density $(\rho)$ changes, point mass balance $b$, and the components of ice flow velocity $w, u$, and $v$ (Cuffey and Paterson, 

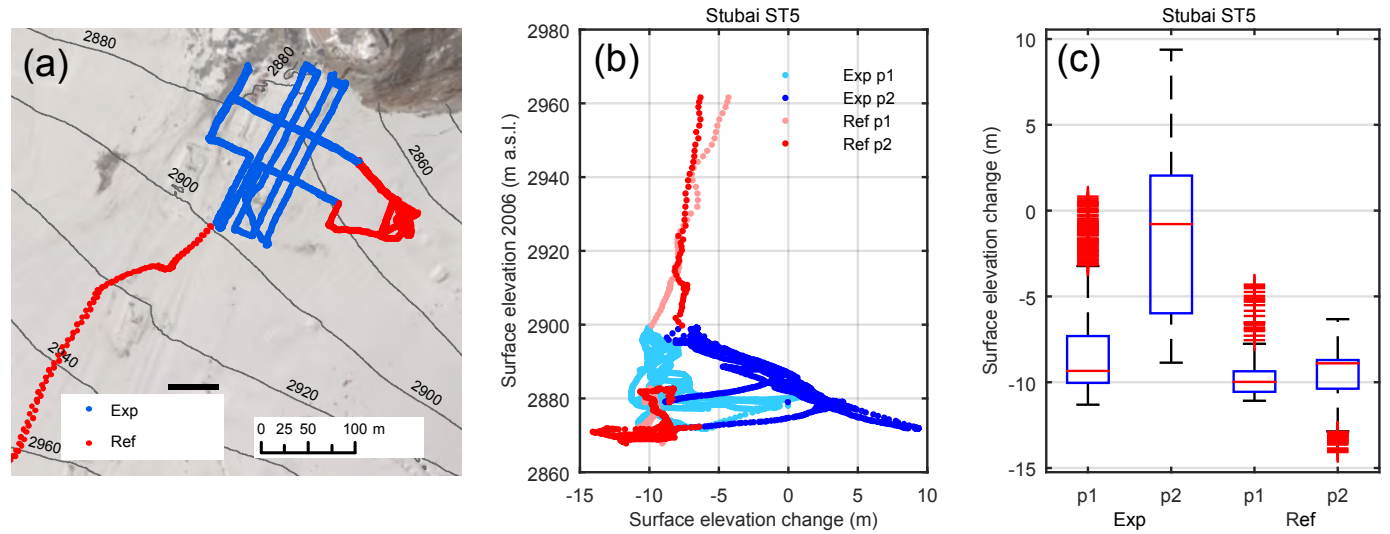

Figure 4. (a) Location of profile ST5, (b) surface elevation changes plotted for surface elevation in 2006, and (c) boxplot of surface elevation changes along the profile separated into experimental areas (exp; in blue) and reference areas (ref; in red) for the periods without (p1; in light colour) and with (p2; in dark colour) mass balance management. Note that similar plots for each profile are provided in the Supplement.

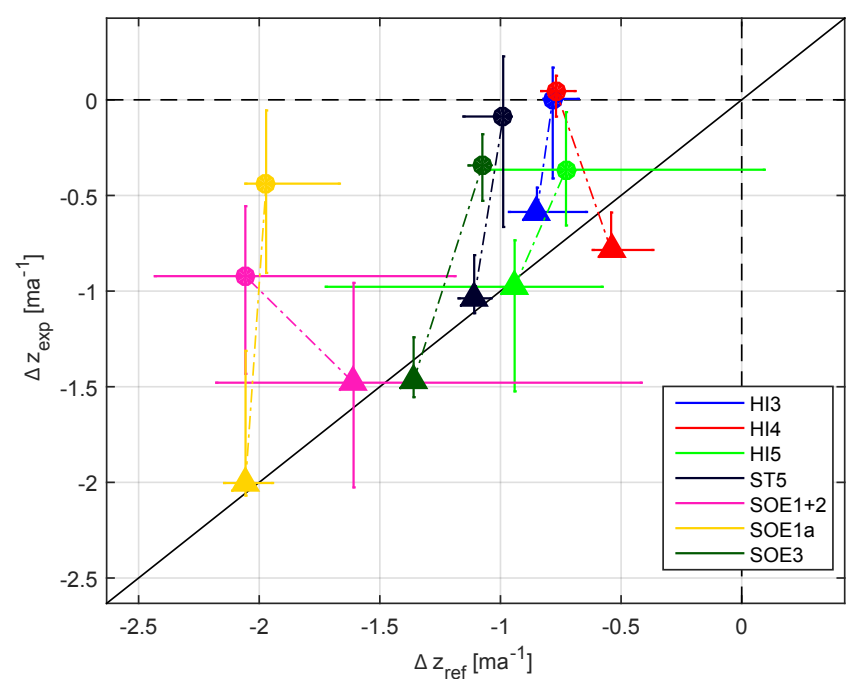

Figure 5. Median of the annual surface elevation changes in reference areas $\left(\Delta z_{\text {ref }}\right)$ compared to the median of the annual surface elevation changes in experimental areas $\left(\Delta z_{\exp }\right)$ for the periods without (triangles) and with (circles) mass balance management. Periods are given in Table 2. Solid lines show the interquartile range between the 25 th and the 75 th percentile. Dashed lines connect the corresponding values of one profile.

2010).

$\frac{\partial S}{\partial t}=\frac{b}{\rho}+w-u \frac{\partial S}{\partial x}-v \frac{\partial S}{\partial x}$

In our study, we measured surface elevation changes $\frac{\partial S}{\partial t}$ at reference and experimental areas. All other parameters are unknown, and modelling results at such a small scale may be dominated by uncertainties of input parameters.

A necessary assumption for being able to compare $\frac{\partial S}{\partial t}$ for experimental and reference areas with obvious and photographically documented differences in mass balance $b$ is

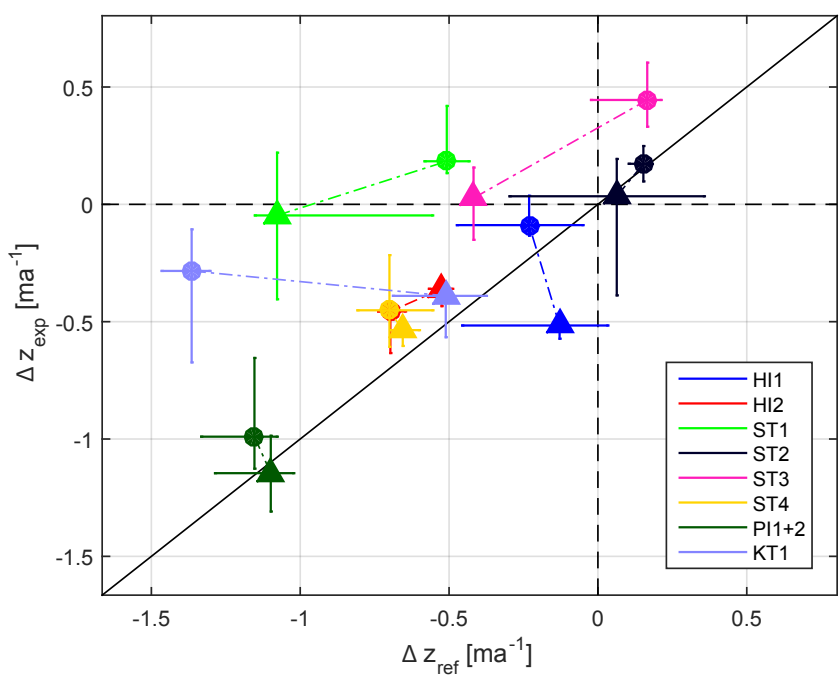

Figure 6. Median of the annual surface elevation changes in reference areas $\left(\Delta z_{\text {ref }}\right)$, compared to the median of the annual surface elevation changes in experimental areas $\left(\Delta z_{\text {ref }}\right)$ for the periods without (triangles) and with (circles) mass balance management. Periods are given in Table 2. Solid lines show the interquartile range between the 25 th and the 75 th percentile. Dashed lines connect the corresponding values of one profile.

that the other components $\left(\rho, w, u, \frac{\partial S}{\partial x} v \frac{\partial S}{\partial x}\right)$ are largely unchanged between experimental and reference areas. Therefore, we have to presume that the components of the surface velocity at the point $u, v$, and $w$ are similar in the experimental and the reference profiles, as well as over the two periods. Then the measured thickness changes are driven by the mass balance measures and not by glacier dynamics. This assumption is not confirmed by measurements of mass balance, densities, or flow velocities but is at least supported by some empirical evidence: (i) the superficial forms at mass balance managed areas are stable during years of field sur- 
veys and in geodata; (ii) very low flow velocities measured generally at Austrian glaciers and in ski resorts glaciers at pylons mean that absolute velocity differences are small; and (iii) the absence of crevasses on the margins of the superficial forms indicate strong gradients of ice flow. The shape of elevation changes in the DEM differences fits the location of the measures, so that a large impact resulting from different or changing ice flow regimes is unlikely.

Horizontal ice flow velocity on Austrian glaciers generally decreased (Fischer, 2015) and so did submergence and emergence (e.g. Span and Kuhn; 2003; Fischer et al., 2011b; Helfricht et al., 2014). Interannual differences in emergence and submergence are less than $0.5 \mathrm{~m} \mathrm{yr}^{-1}$ on Kesselwandferner (Fischer et al., 2011b).

However, this study does not focus on the absolute values of surface elevation changes or mass balance. The aim is to analyse the differences between maintained glacier areas and areas with limited maintenance nearby. In the profile plots all measurement points are shown along the elevation range of the profile so that differences caused by the measurement setup show up immediately. All reference surfaces are subject to grooming during winter; only in Hintertux glacier ski resort are pistes also groomed in summer. Local mass balance measurements indicate that grooming in winter without other measures reduces ice ablation in summer by $10 \%$ because of limiting the wind erosion of snow (Fischer et al., 2011a). This study did not investigate the effect of grooming in summer (without application of other measures) on albedo, which is presumed e.g. by Keller et al. (2004). Relocation of snow by snowcats mainly takes advantage of periglacial snow or even, in addition to deposits gained by blasting avalanches on periglacial slopes.

Differences between mass balance managed areas and reference areas are within the range of uncertainty for the first period DEM differences but not for the second period, for which high accuracy geodata are available.

In general the absolute values of the mean surface elevation changes strongly depend on the chosen path or profile line and do not represent mean glacier mass balance at these elevations. Often the basis of pylons and lift traverses are covered to retain them over a period of several years, until the pylons have to be relocated to compensate for the ice flow. After stopping the mass balance management, these features, at first standing proud from the glacier surface, disappear fast. This can be explained by the enlarged surface of the feature in relation to its volume. Thus the increase of energy exchange will cause higher melt until the surface is minimized and evens out with the nearby surfaces. Additionally, less snow is accumulated on it, because the surface is more exposed to wind.

Mass balance management at the glacier tongues may be feasible as long as the area to be managed remains small and needs not to be extended to larger areas up-glacier. However, mass balance management shows the potential to keep the surface constant at highest elevations of the glaciers and thus conserve the firn reservoirs. This might have a long-term impact on the future existence since the natural glacier equilibrium line altitude in recent years often exceed peak elevation (Fischer et al., 2013a, 2014a, b). Thus, specific mass balance management in the typical firn areas is more sustainable with respect to future glacier extent than mass balance management at the tongues.

The economic benefit results from costs and gains, with costs for all investments being easier to capture than the gains. The total costs of glacier covers are those of material and maintenance. Material/investment costs include sheets and bags filled with gravel for fixing the sheets on the glacier, and storage space. Maintenance costs include transport, mounting, maintenance on the glacier, and removal of the material, both personnel and machinery costs. Depending on individual settings, total annual costs are about 1.5 EUR m ${ }^{-2}$, divided about 50:50 between material and maintenance. The uncertainty about the economic benefits is much higher because, even with detailed visitor questionnaires, the costs of loss of glacier area for ski slopes is hard to quantify. In addition to that, the costs of the loss of glacier area or altitude are highly individual: if a ski lift has to be rebuilt, economic costs of glacier loss are quite high. Currently, mass balance management extends to Tignes (France), Whistler (BC), Mount Hood (OR) (all M. Pelto, comment to TCD discussion paper), Mölltal Glacier (AT), Kitzsteinhorn (AT), Dachstein (AT), Zugspitze (D), Saas Fee (CH), and Schnalstal Glacier (IT).

A wider application of the methods for meltwater management has been proven for Armenia (Nestler et al., 2014). An application in high-lying regions in Central Asia could be feasible: albedo has been shown to be a major factor governing mass balance (e.g. Fujita and Ageta, 2000), so that the application of geotextiles will reduce melt in the absence of seasonal snow falls. As the covers can be placed and removed at nearly any time (unless superimposed ice forms on them), an effective water management seems possible. Drawbacks of the method are the need for machinery for an application on areas larger than about $100 \times 100 \mathrm{~m}$ and the costs.

An application of geotextile covers to ski resorts at lower elevations (e.g. without glacier cover) is not straightforward, as the sensible rather than the radiative energy flux is decisive here. This makes mass balance management by relocation of snow often combined with insulating measured as wood chips more effective than the albedo increase by geotextiles (Skogsberg and Lundberg, 2005; Grünewald and Wolfsperger, 2016).

\section{Conclusions}

The use of snow production, relocation of snow, and glacier covering shows good results in preserving the surface elevation on the decadal timescale. Over the observed time periods, the reduction in surface elevation caused by glacier 
retreat could be reduced locally by more than $1.3 \mathrm{~m} \mathrm{yr}^{-1}$. This is more than the long-term mean thickness change of all ski resort glaciers of $-0.8 \mathrm{~m} \mathrm{yr}^{-1}$ (1997-2006; Fischer et al., 2011). Mass balance management measures thus do a good job in stemming surface elevation decrease on a small proportion of the area of ski resort glaciers where the measures can be applied. The differences between mass balance managed areas and reference areas cover a wide range of values, as do the thickness changes. Largest thickness changes are found close to the glacier tongues, and here the highest absolute effects of measures are found. Although the reduction of thickness changes is smaller in higher areas and areas with lower thickness losses in reference areas, this does not mean that measures are less effective there: in four of 15 profiles, surface elevation in mass balance managed areas increased, while reference areas showed a continuous decrease of surface elevation.

In the uppermost parts of the glaciers, the preservation of surface elevation by covering the glacier works well to retain the piste connection between ropeway mountain stations and the glacier surface over multi-year periods. The long-term use of glacier cover in the upper parts of the glaciers (e.g. ST1, ST2) may affect the existence of these glacier sections in future, because equilibrium line altitudes of glacier mass balances have exceeded peak elevations in recent years. In areas near the glacier terminus, the continuous combination of additional snow load and glacier cover helps to preserve the remaining ice body where, without mass balance management, the glacier would retreat rapidly. Practical limitations on the application of mass balance measures arise from the evolving small-scale topography.

The measures have been carried out at small areas only, as costs and labour restrict the application to the most sensitive areas, i.e. the interface between subsiding parts of the glacier and technical infrastructure like stations and pylons. This also limits the impact of local measures on total glacier mass balance.

Our study complemented previous research on the positive effect of mass balance management on local mass and energy balance and was able to demonstrate that there is a positive long-term impact of measures on elevation change. Nevertheless, in the light of technical and practical limitations of the measures, and the extreme melt rates of the early 21 st century, such measures can only delay the decay of glaciers in ski resorts. The question remains whether the well-investigated effect of thick enough debris cover reducing ice melt might be technically applicable for glacier ski resorts. Important points to investigate would be the stability of debris depending on slope inclination and liquid water (rain and melt water), the optimum size and structure of the debris, and the potential to create smooth surfaces, prohibiting the evolution of melting ponds and steep ridges.

\section{Data availability}

The glacier documents of the compilation and the glacier outlines of the Austrian glacier inventories are available as cited. For the DEMs, several restrictions apply, as the data is (for early inventories: partly) property of federal authorities. DGPS data is published at the pangaea data base as cited.

\section{The Supplement related to this article is available online at doi:10.5194/tc-10-2941-2016-supplement.}

Acknowledgements. The authors thank the Austrian glacier ski resorts for the constructive cooperation, logistic help for in situ measurements and providing the 2014 lidar DEM data. The lidar DEM data of 2012 were provided from the joint project PROSA funded by the German Research Foundation (DFG) (SCHM 472/17-1 and SCHM 472/17-2) and the Austrian Science Fund (FWF) (I 894-N24 and I 1646-N19). The constructive comments of two anonymous reviewers and Mauri Pelto were very helpful for improving the manuscript. We are grateful to Brigitte Scott for the English editing.

Edited by: C. R. Stokes

Reviewed by: two anonymous referees

\section{References}

Abermann, J., Lambrecht, A., and Schneider, H.: Analysis of surface elevation changes on Kesselwand glacier - Comparison of different methods, Zeitschrift für Gletscherkunde und Glazialgeologie, 41, 147-168, 2007.

Abermann, J., Lambrecht, A., Fischer, A., and Kuhn, M.: Quantifying changes and trends in glacier area and volume in the Austrian Ötztal Alps (1969-1997-2006), The Cryosphere, 3, 205215, doi:10.5194/tc-3-205-2009, 2009.

Abermann, J., Fischer, A., Lambrecht, A., and Geist, T.: On the potential of very high-resolution repeat DEMs in glacial and periglacial environments, The Cryosphere, 4, 53-65, doi:10.5194/tc-4-53-2010, 2010.

Bollmann, E., Sailer, R., Briese, C., Stötter, J., and Fritzmann, P.: Potential of airborne laser scanning for geomorphologic feature and process detection and quantifications in high alpine mountains, Z. Geomorphol. Supp., 55, 83-104, doi:10.1127/03728854/2011/0055S2-0047, 2011

Cogley, J. G., Hock, R., Rasmussen, L. A., Arendt, A. A., Bauder, A., Braithwaite, R. J., Jansson, P., Kaser, G., Möller, M., Nicholson, L., and Zemp, M.: Glossary of Glacier Mass Balance and Related Terms, IHP-VII Technical Documents in Hydrology No. 86, IACS Contribution No. 2, UNESCO-IHP, Paris, 124 pp., 2011.

Colgan, W., Rajaram, H., Abdalati, W., McCutchan, C., Mottram, R., Moussavi, M., and Grigsby, S.: Glacier crevasses: Observations, models, and mass balance implications, Rev. Geophys. 54, 119-161, doi:10.1002/2015RG000504, 2016. 
Deems, J. S., Painter, T. H., and Finnegan, D. C.: Lidar measurement of snow depth: a review, J. Glaciol., 59, 467-479, doi:10.3189/2013JoG12J1542013.

Diolaiuti, G., Smiraglia, C., Pelfini, M., Belò, M., Pavan, M., and Vassena, G.: The recent evolution of an Alpine glacier used for summer skiing (Vedretta Piana, Stelvio Pass, Italy), Cold Reg. Sci. Technol., 44, 206-216, doi:10.1016/j.coldregions.2005.11.006, 2006.

Fahey, B., Wardle, K., and Weir, P.: Environmental effects associated with snow grooming and skiing at Treble Cone Ski Field. Part 2. Snow properties on groomed and non-groomed slopes, Sci. Conserv., 120B, 49-62, 1999.

Fischer, A.: Glaciers and climate change: Interpretation of 50 years of direct mass balance of Hintereisferner, Global Planet. Change, 71, 13-26, doi:10.1016/j.gloplacha.2009.11.014, 2010.

Fischer, A.: Sammelbericht über die Gletschermessungen des Österreichischen Alpenvereins im Jahre 2014, Bergauf, 02/2015, 26-33, 2015.

Fischer, A., Olefs, M., and Abermann, J.: Glaciers, snow and ski tourism in Austria's changing climate, Ann. Glaciol., 52, 89-96, doi:10.3189/172756411797252338, 2011a.

Fischer, A., Schneider, H., Merkel, G., and Sailer, R.: Comparison of direct and geodetic mass balances on an annual time scale, The Cryosphere Discuss., 5, 565-604, doi:10.5194/tcd-5-565-2011, 2011b.

Fischer, A., Markl, G., and Kuhn, M.: Glacier mass balances and elevation zones of Hintereisferner, Ötztal Alps, Austria, 1952/1953 to 2010/2011, Institute for Interdisciplinary Mountain Research, PANGAEA, doi:10.1594/PANGAEA.818898, 2013a.

Fischer, A., Patzelt, G., and Kinzl, H.: Length changes of Austrian glaciers 1969-2014. Institute for Interdisciplinary Mountain Research, PANGAEA, doi:10.1594/PANGAEA.821823, 2013b.

Fischer, A., Markl, G., Schneider, H., Abermann, J., and Kuhn, M.: Glacier mass balances and elevation zones of Kesselwandferner, Ötztal Alps, Austria, 1952/1953 to 2012/2013, Institute for Interdisciplinary Mountain Research, PANGAEA, doi:10.1594/PANGAEA.818757, 2014a.

Fischer, A., Stocker Waldhuber, M., Seiser, B., Hynek, B., and Slupetzky, H.: Glaciological Monitoring in the Hohe Tauern National Park, ecomont, 6, 55-62, 2014b.

Fischer, A., Seiser, B., Stocker Waldhuber, M., Mitterer, C., and Abermann, J.: Tracing glacier changes in Austria from the Little Ice Age to the present using a lidar-based high-resolution glacier inventory in Austria, The Cryosphere, 9, 753-766, doi:10.5194/tc-9-753-2015, 2015.

Fujita, K. and Ageta Y.: Effect of summer accumulation on glacier mass balance on the Tibetan Plateau revealed by massbalance model, J. Glaciol., 46, 244-252, available at: http:// www.cryoscience.net/pub/pdf/2000jg_fujita.pdf (last access: 21 November 2016), 2000.

Grünewald, T. and Wolfsperger, F.: Storing snow for the next winter: Two case studies on the application of snow farming, Geophys. Res. Abstr., 18, EGU2016-8384, 2016.

Helfricht, K., Kuhn, M., Keuschnig, M., and Heilig, A.: Lidar snow cover studies on glaciers in the Ötztal Alps (Austria): comparison with snow depths calculated from GPR measurements, The Cryosphere, 8, 41-57, doi:10.5194/tc-8-41-2014, 2014.

Hijioka, Y., Lin, E., Pereira, J. J., Corlett, R. T., Cui, X., Insarov, G. E., Lasco, R. D., Lindgren, E., and Surjan, A.: Asia, in: Cli- mate Change 2014: Impacts, Adaptation, and Vulnerability. Part B: Regional Aspects, Contribution of Working Group II to the Fifth Assessment Report of the Intergovernmental Panel on Climate Change, edited by: Barros, V. R., Field, C. B., Dokken, D. J., Mastrandrea, M. D., Mach, K. J., Bilir, T. E., Chatterjee, M., Ebi, K. L., Estrada, Y. O., Genova, R. C., Girma, B., Kissel, E. S., Levy, A. N., MacCracken, S., Mastrandrea, P. R., and White, L. L., Cambridge University Press, Cambridge, UK and New York, NY, USA, 1327-1370, 2014.

Joerg, P. C., Morsdorf, F., and Zemp, M.: Uncertainty assessment of multi-temporal airborne laser scanning data: A case study on an Alpine glacier, Remote Sens. Environ., 127, 118-129, doi:10.1016/j.rse.2012.08.012, 2012.

Keller, T., Pielmeier, C., Rixen, C., Gadient, F., Gustafsson, D., and Stähli, M.: Impact of artificial snow and skislope grooming on snowpack properties and soil thermal regime in a sub-alpine ski area, Ann. Glaciol., 38, 314-318, doi:10.3189/172756404781815310, 2004.

Kovats, R. S., Valentini, R., Bouwer, L. M., Georgopoulou, E., Jacob, D., Martin, E., Rounsevell, M., and Soussana, J.-F.: Europe, in: Climate Change 2014: Impacts, Adaptation, and Vulnerability. Part B: Regional Aspects. Contribution of Working Group II to the Fifth Assessment Report of the Intergovernmental Panel on Climate Change, edited by: Barros, V. R., Field, C. B., Dokken, D. J., Mastrandrea, M. D., Mach, K. J., Bilir, T. E., Chatterjee, M., Ebi, K. L., Estrada, Y. O., Genova, R. C., Girma, B., Kissel, E. S., Levy, A. N., MacCracken, S., Mastrandrea, P. R., and White, L. L. Cambridge University Press, Cambridge, UK and New York, NY, USA, 1267-1326, 2014.

Lambrecht, A. and Kuhn, M.: Glacier changes in the Austrian Alps during the last three decades, derived from the new Austrian glacier inventory, Ann. Glaciol., 46, 177-184, doi:10.3189/172756407782871341, 2007.

Monteiro, L. S., Moore, T., and Hill, C.: What is the accuracy of DGPS?, J. Navigation, 58, 207-225, doi:10.1017/S037346330500322X, 2005.

Nestler, A., Huss, M., Ambartzumian, R., and Hambarian, A.: Hydrological Implications of Covering Wind-Blown Snow Accumulations with Geotextiles on Mount Aragats, Armenia, Geosciences, 4, 73-92, doi:10.3390/geosciences4030073, 2014.

Norphel, C. and Padma, T.: Snow Water Harvesting in the Cold Desert in Ladakh: An Introduction to Artificial Glacier, in: Mountain Hazards and Disaster Risk Reduction, edited by: Nibanupudi, K. H. and Shaw, R., 199-210, Springer Japan, doi:10.1007/978-4-431-55242-0_11, 2015.

Olefs, M. and Fischer, A.: Comparative study of technical measures to reduce snow and ice ablation in Alpine glacier ski resorts, Cold Reg. Sci. Technol., 52, 371-384, doi:10.1016/j.coldregions.2007.04.021, 2008.

Olefs, M. and Lehning, M.: Textile protection of snow and ice: Measured and simulated effects on the energy and mass balance, Cold Reg. Sci. Technol., 62, 126-141, doi:10.1016/j.coldregions.2010.03.011, 2010.

Olefs, M. and Obleitner, F.: Numerical simulations on artificial reduction of snow and ice ablation, Water Resour. Res., 43, W06405, doi:10.1029/2006WR005065, 2007.

Pelto, M. S. and Hedlund, C.: The terminus behavior and response time of North Cascade glaciers, J. Glaciol., 47, 497-506, doi:10.3189/172756501781832098, 2001. 
Sailer, R., Rutzinger, M., Rieg, L., and Wichmann, V.: Digital elevation models derived from airborne laser scanning point clouds: appropriate spatial resolutions for multi-temporal characterization and quantification of geomorphological processes, Earth Surf. Proc. Land., 39, 272-284, doi:10.1002/esp.3490, 2014.

Skogsberg, K. and Lundberg, A.: Wood chips as thermal insulation of snow, Cold Reg. Sci. Technol., 43, 207-218, doi:10.1016/j.coldregions.2005.06.001, 2005.

Smiraglia, C., Diolaiuti, G., Pelfini, M., Belò, M., Citterio, M., Carnielli, T., and D'Agata, C.: Glacier changes and their impacts on mountain tourism: two case studies from the Italian Alps, in: Darkening peaks: glacier retreat, science and society, edited by: Orlove, B., Wiegandt, E., and Luckman, B. H., University of California Press, Berkeley, CA, 206-215, 2008.

Span, N. and Kuhn, M.: Simulating annual glacier flow with a linear reservoir model, J. Geophys. Res.-Atmos., 108, 4313, doi:10.1029/2002JD002828oi, 2003.

Spandre, P., Morin, S., Lafaysse, M., Lejeune, Y., Francois, H., and George-Marcelpoil, E.: Integration of snow management processes into a detailed snowpack model, Cold Reg. Sci. Technol., 125, 48-64, doi:10.1016/j.coldregions.2016.01.002, 2016.

Vaughan, D. G., Comiso, J. C., Allison, I., Carrasco, J., Kaser, G., Kwok, R., Mote, P., Murray, T., Paul, F., Ren, J., Rignot, E., Solomina, O., Steffen, K., and Zhang, T.: Observations: Cryosphere, in: Climate Change 2013: The Physical Science Basis, Contribution of Working Group I to the Fifth Assessment Report of the Intergovernmental Panel on Climate Change, edited by: Stocker, T. F., Qin, D., Plattner, G. K., Tignor, M., Allen, S. K., Boschung, J., Nauels, A., Xia, Y., Bex, V., and Midgley, P. M., 4, 317-382, Cambridge University Press, 2013.
Würländer, R. and Eder, K.: Leistungsfähigkeit aktueller Photogrammetrischer Auswertemethoden zum Aufbau eines eines digitalen Gletscherkatasters, Zeitschrift für Gletscherkunde und Glazialgeologie, 35, 167-185, 1998.

Zemp, M., Frey, H., Gärtner-Roer, I., Nussbaumer, S. U., Hoelzle, M., Paul, F., Haeberli, W., Denzinger, F., Ahlstrøm, A. P., Anderson, B., Bajracharya, S., Baroni, C., Braun, L. N., Cáceres, B. E., Casassa, G., Cobos, G., Dávila, L. R., Delgado Granados, H., Demuth, M. N., Espizua, L., Fischer, A., Fujita, K., Gadek, B., Ghazanfar, A., Hagen, J. O., Holmlund, P., Karimi, N., Li, Z., Pelto, M., Pitte, P., Popovnin, V. V., Portocarrero, C. A., Prinz, R., Sangewar, C. V., Severskiy, I., Sigurðsson, O., Soruco, A., Usubaliev, R., and Vincent, C.: Historically unprecedented global glacier decline in the early 21 st century, J. Glaciol., 61, 745-762, doi:10.3189/2015JoG15J017, 2015. 